\title{
Peningkatan Kemampuan Analisis Melalui Strategi PQ4R (Preview, Question, Read, Recite, Reflect, Review) Pada Pembelajaran IPA Sekolah Dasar
}

\author{
Sri Lestari Handayani ${ }^{1}$, Meike Anjar Dewanti ${ }^{2}$ \\ ${ }^{1}$ Pendidikan Guru Sekolah Dasar, Fakultas Keguruan dan Ilmu Pendidikan, Universitas \\ Muhammadiyah Prof. Dr. HAMKA \\ ${ }^{2}$ Pendidikan Dasar, Universitas Muhammadiyah Prof. Dr. HAMKA, SD Negeri Cipayung Depok, \\ Jawa Barat \\ 1'srilestarih@uhamka.ac.id
}

\begin{abstract}
ABSTRAK
Penelitian memiliki tujuan untuk meningkatkan kemampuan analisis siswa Sekolah Dasar (SD) dengan menerapkan strategi pembelajaran PQ4R (Preview, Question, Read, Recite, Reflect, Review). Penelitian ini adalah Penelitian Tindakan Kelas (PTK). PTK yang dilakukan dalam dua siklus. Setiap siklus terdiri dari empat tahap yaitu perencanaan pembelajaran, pelaksanaan pembelajaran, observasi dan refleksi. Subjek penelitian ini adalah Kelas V SD Negeri Cipayung Depok yang berjumlah 28 siswa. Teknik pengumpulan data yang digunakan pada penelitian ini menggunakan tes dan observasi. Tes yang digunakan berupa tes tertulis berbentuk soal uraian. Instrumen observasi menggunakan lembar observasi. Teknik analisis data berupa teknik analisis data deskriptif berupa prosentase ketuntasan belajar pada masing-masing siklus. Pada siklus I, diperoleh hasil bahwa rata-rata kemampuan analisis siswa sebesar 75,07 dan ketuntasan belajar siswa sebanyak strategi model pembelajaran PQ4R dapat meningkatkan kemampuan analisis siswa. Hal ini terjadi karena ada peningkatan kualitas pembelajaran yang dialami oleh siswa melalui pembelajaran P4QR meliputi peningkatan keaktifan siswa baik dalam bentuk minat belajar, perhatian terhadap pelajaran, angka partisipasi, dan presentasi peserta didik dalam kegiatan pembelajaran IPA.
\end{abstract}

Kata kunci: Kemampuan Analisis, PQ4R, Ilmu Pengetahuan Alam, Sekolah Dasar

\section{ABSTRACT}

This research aims to improve the analytical skills of elementary school students by applying the PQ4R learning strategy (Preview, Question, Read, Recite, Reflect, Review). This research is a Classroom Action Research (PTK). The PTK carried out in this study was carried out in two cycles. Each cycle consists of learning planning activities, learning implementation processes, observation and reflection activities. The subjects of this study were Class V SD Negeri Cipayung, Sukmajaya District, Depok City, totaling 28 students. The data collection techniques used in this study were tests and observations. The test used is a written test in the form of description questions. The observation instrument uses the observation sheet. The data analysis technique is in the form of descriptive data analysis technique in the form of the percentage of completeness of learning in each cycle. In the first cycle, it was found that the average student's analytical ability was 75.07 and the student's learning completeness was $67.86 \%$. In the second cycle, it was found that the average student's analytical skills were $85.71 \%$ and student learning completeness was $85.71 \%$. Based on these results, it can be stated that the PQ4R learning strategy can improve students' analytical skills. This happens because there is an increase in the quality of learning experienced by students through P4QR learning including increasing student activity in the form of interest in learning, attention to lessons, participation rates, and student presentations in science learning activities.

Keywords: Analysis Skill, PQ4R, Science, Elemenatry School.

\section{PENDAHULUAN}

Berdasarkan hasil survey TIMSS

(Trends in International Mathematics and

Science Study) tahun 2007 Indonesia menduduki peringkat 36 dari 49 negara dengan nilai 427, padahal skor rata-rata internasional adalah 500. Tahun 2015 Indonesia turun ke peringkat 45 dari 48 negara dengan skor 397 
meskipun skor rata-rata sebesar 501 (Sayekti, 2016). Perbedaan hasil tersebut menjadi indikator rendahnya kondisi dan kualitas pendidikan di Indonesia. Berdasarkan hasil yang diperoleh dari TIMSS kemampuan sampel dari siswa Indonesia belum memiliki kapabilitas yang cukup untuk memecahkan masalah ranah kognitif tinggi. Oleh karena itu, saat ini pembelajaran Ilmu Pengetahuan Alam (IPA) di sekolah terus diupayakan dengan cara mengoptimalkan kemampuan analisis siswa menggunakan beberapa model pembelajaran yang tepat (Irianto et al., 2015). Membelajarkan IPA termasuk di tingkat SD bertujuan membelajarkan peristiwa-peristiwa yang terjadi di alam dengan melakukan observasi, eksperimen, penyimpulan, penyusunan teori agar siswa mempunyai pengetahuan, gagasan dan konsep yang terorganisasi tentang alam sekitar, yang diperoleh dari pengalaman melalui serangkaian proses ilmiah (Dewi et al., 2018; Mukhbitah et al., 2019).

Pada saat membelajarkan muatan pelajaran IPA di SD ditemukan beberapa permasalahan. Permasalahannya yang ditemukan diantaranya (1) kurangnya pemahaman siswa terhadap materi yang disampaikan oleh guru dikarenakan siswa tidak menyimak penjelasan guru secara seksama, (2) Jika diberikan soal evaluasi formatif, siswa cenderung hanya menyalin jawaban dari sumber belajar tanpa menganalisis soal terlebih dahulu dan tidak menalar jawaban sendiri, (3) sebagian besar siswa menganggap bahwa materi pembelajaran IPA sangatlah mudah, sehingga timbul rasa menyepelekan untuk mempelajari pelajaran IPA secara kompleks, (4) proses pembelajaran yang dilakukan belum optimal. Proses pembelajaran yang diberikan belum menunjukkan kearah teaching of thinking yaitu pembentukan keterampilan mental tertentu seperti keterampilan metakognitif, berpikir kritis, dan berfikir analisis siswa. Hal tersebut karena rancangan yang telah dibuat oleh guru belum memfasilitasi siswa dalam memberdayakan keterampilan metakognitif dan berpikir kritis. Jika situasi pembelajaran tersebut yang telah dilaksanakan tidak segera diatasi oleh guru maka dapat berdampak negatif terhadap kemampuan analisis siswa yang tentu saja sangat berhubungan dengan prestasi belajar IPA secara keseluruhan.

Analisis merupakan aktivitas yang melibatkan daya pikir untuk menelaah sesuatu seperti menghitung, mencari faktor penyebab sesuatu, mengurutkan, mencari alur, mengelompokkan, dan sebagainya. Dalam aktivitas ini, kemampuan logika siswa sangat penting untuk mencapai hasil analisis yang akurat (Novita et al., 2016). Aktivitas ini sangat berguna untuk melatih siswa menemukan sebab dari segala persoalan yang dihadapinya seharihari dan kemudian mencari cara untuk menyelesaikannya. Kemampuan analisis berada pada domain proses kognitif tingkat tinggi atau menjadi salah satu keterampilan berfikir tingkat tinggi. Kemampuan analisis siswa adalah kemampuan siswa dalam menerangkan hubungan-hubungan yang ada dan mengkombinasi unsur-unsur menjadi satu kesatuan. (Achmad, 2016; Novita et al., 2016; Qomariya et al., 2018). Kemampuan analisis ini mencakup tiga proses yaitu siswa dapat mengurai unsur informasi yang relevan, menentukan hubungan antara unsur yang relevan, dan menentukan sudut pandang tentang tujuan dalam mempelajari suatu informasi.

Indikator kemampuan analisis menurut meliputi (a) kemampuan membedakan, (b) kemampuan mengorganisasi, dan (c) kemampuan mengatribusi (Astriani et al., 2017; Nawawi et al., 2017). Kemampuan membedakan adalah kemampuan yang dimiliki siswa dalam memilah atau membagi suatu informasi menjadi beberapa bagian berdasarkan relevansi dan penting atau tidaknya. Kemampuan mengorganisasi yaitu kemampuan dalam melakukan identifikasi unsur-unsur situasi dan mengenali keterkaitan diantara unsur-unsur tersebut untuk membentuk suatu struktur yang koheren. Kemampuan mengatribusi adalah kemampuan dalam menentukan sudut pandang, pendapat, dan tujuan dibalik suatu komunikasi atau disebut dengan mendekontruksi. Kemampuan berfikir analisis menjadi salah satu keterampilan abad 21 yang harus dikuasai siswa. Kurangnya keterampilan analisis dapat memberikan dampak tidak baik bagi siswa dalam jangka pendek maupun jangka panjang. Dampak jangka pendek dapat dilihat dari segi hasil belajar siswa yang tidak optimal. Dampak jangka panjang dapat diketahui dari siswa yang memiliki kualitas penguasaan keterampilan abad 21 yang tidak maksimal.

Kemampuan berfikir analisis siswa dapat diasah melalui proses pembelajaran namun tetap menyesuaikan perkembangan berfikir siswa (Rosadi \& Sunarno, 2018). Pembelajaran yang menekankan pada kemampuan analisis sudah dapat dimaksimalkan saat siswa masuk pada usia rentang 7-11 tahun. Tahap berfikir siswa yang 
berusi 7 - 11 tahun berada pada tahap konkretoperasional dimana siswa dapat diajak untuk berfikir logis tentang peristiwa-peristiwa yang konkret dan mengklasifikasikan benda-benda ke dalam bentuk-bentuk yang berbeda. Pada tahap ini, siswa dapat diajak untuk berfikir secara menalar mengenai pengetahuan yang siswa tersebut lakukan.

Mengoptimalkan kemampuan analisis siswa khususnya dalam muatan pelajaran IPA berarti menciptakan proses pembelajaran yang mengoptimalkan kemampuan siswa dalam menerangkan hubungan-hubungan yang ada dan mengkombinasi unsur-unsur menjadi satu kesatuan yang mencakup tiga proses, yaitu siswa dapat mengurai unsur informasi yang relevan, menentukan hubungan antara unsur yang relevan, dan menentukan sudut pandang tentang tujuan dalam mempelajari suatu informasi dalam konteks pembelajaran IPA. Proses pembelajaran yang menekankan proses mengembangkan kemampuan analisis siswa dapat dilakukan dengan menciptakan pembelajaran kooperatif (Pasinggi, 2016). Salah satu strategi yang dapat diterapkan adalah PQ4R yang meliputi Preview, Question, Read, Recite, Review, dan Reflect. Pada tahap Preview (meneliti), siswa diharapkan meneliti dan menjajaki materi ajar untuk mendapatkan suatu ide atau dasar pemikiran tentang materi tersebut, sehingga siswa dapat meramalkan apa saja yang akan dipelajari. Hal ini dapat dilakukan dengan memberi perhatian pada judul (pokok bahasan), dan sub judul (sub pokok bahasan) dalam waktu yang cukup singkat. Tahap Question (bertanya), siswa diminta membuat dan mengajukan pertanyaan atau soal kepada dirinya sendiri tentang materi itu pada saat membaca atau mempelajari pokok bahasan tersebut. Tahap Read (membaca), siswa diharapkan belajar dengan membaca materi ajar yang sedang dibahas. Tahap Recite (menceritakan kembali), siswa diharapkan dapat menceritakan konsep-konsep atau pengetahuan-pengetahuan yang diperoleh dengan bahasa atau kalimat sendiri secara utuh. Tahap Review (meninjau kembali), siswa dapat meninjau kembali materi yang telah dipelajari dan memusatkan diri pada soal-soal dan jawaban serta gagasan-gagasan yang diperoleh pada langkah sebelumnya. Tahap Reflect (refleksi), siswa memikirkan tentang apa yang baru dipelajari, kemudian membuat hubunganhubungan antara pengetahuan yang dimiliki sebelumnya dengan pengetahuan yang baru diperolehnya. Pada tahap ini, siswa diharapkan untuk berpikir kritis serta analisis tentang kesimpulan yang diperoleh pada tahap review. Melalui kegiatan ini, siswa dapat memperoleh sesuatu yang berguna bagi dirinya tentang apa yang baru dipelajarinya.

Pratiwi dalam Al-Tabany (2014) menyatakan bahwa strategi ini dapat digunakan untuk membantu siswa mengingat apa yang mereka baca dan dapat membantu proses pembelajaran di kelas yang dilaksanakan dengan kegiatan membaca buku. Aktivitas atau kegiatan seseorang membaca buku mmeiliki tujuan untuk mempelajari mendalam materi yang berada pada satu bab kemudian melanjutkan ke bab berikutnya dengan tuntas. Oleh karena itu keterampilan pokok pertama yang harus dikembangkan dan dikuasahi oleh siswa adalah membaca buku pelajaran dan bacaan tambahan lainnya (Al-Tabany, 2014). Pembelajaran PQ4R menerapkan pola pembelajaran berkelompok yang didalamnya terdapat aktivitas kerjasama siswa dengan terarah (Ahmad \& Damayanti, 2013; Pramana et al., 2014). Pada umumnya tiap kelompok terdiri dari 4-6 orang dengan struktur kelompok yang bersifat heterogen. Pembelajaran PQ4R berbasis kontekstual merupakan suatu pembelajaran dimana siswa dituntut untuk menemukan sendiri konsep pembelajaran melalui kegiatan membaca secara aktif dan sistematis (Pramana et al., 2014). Langkahlangkah pembelajaran $\mathrm{P} 4 \mathrm{QR}$ memperhatikan ketujuh komponen pendekatan kontekstual lainnya, yaitu konstruktivisme, inkuiri, bertanya, masyarakat belajar, pemodelan, refleksi dan penilaian autentik. Terdapat kelebihan dan kekurangan yang dimiliki oleh strategi PQ4R. Kelebihan strategi PQ4R meliputi (1) Sangat tepat digunakan untuk pengajaran pengetahuan yang bersifat deklaratif berupa konsep- konsep, definisi, kaidah-kaidah, dan pengetahuan penerapan dalam kehidupan sehari-hari, (2) Mudah diterapkan pada semua jenjang pendidikan, (3) Dapat membantu siswa yang daya ingatannya lemah untuk menghapal konsep-konsep pelajaran, (4) Mampu membantu siswa dalam meningkatkan keterampilan proses bertanya dan mengomunikasikan pengetahuannya, (5) Dapat menjangkau materi pelajaran dalam cakupan yang luas. Kekurangan strategi PQ4R diantaranya (1) Tidak tepat diterapkan pada pengajaran pengetahuan yang bersifat prosedural seperti pengetahuan keterampilan, (2) Tidak efektif dilaksanakan pada kelas dengan jumlah siswa yang telalu besar karena bimbingan guru tidak maksimal terutama dalam merumuskan pertanyaan, dan (3) Sangat sulit 
dilaksanakan jika sarana seperti buku siswa (buku paket) tidak tersedia di sekolah. Tujuan penelitian ini adalah upaya meningkatkan kemampuan berfikir analisis siswa SD Negeri Cipayung kelas 5 dengan menerapkan strategi pembelajaran PQ4R pada IPA materi struktur lapisan bumi.

\section{METODE PENELITIAN}

Penelitian ini merupakan penelitian tindakan kelas, karena penelitian ini dilakukan untuk memecahkan masalah pembelajaran di kelas. Penelitian ini mengacu pada perbaikan pembelajaran yang berkesinambungan. Siklus penelitian tindakan kelas dimulai dari perencanaan atau pelaksanaan observasi dan refleksi. Penelitian ini dilakukan sebanyak dua siklus. Selengkapnya dua siklus dapat dilihat pada Gambar 1.

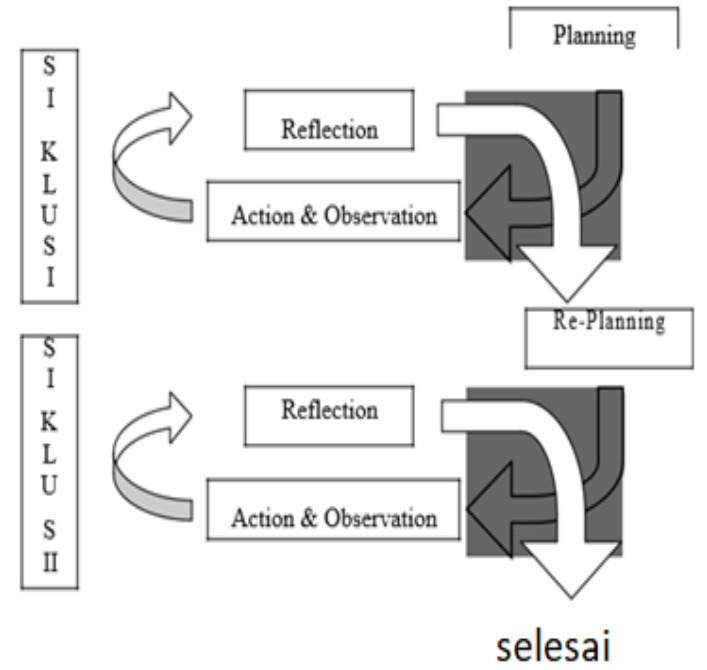

Gambar 1. Siklus Pelaksanaan PTK

Penelitian ini dilaksanakan di SD Negeri Cipayung Kecamatan Sukmajaya Kota Depok 28 siswa. Teknik pengumpulan data pada penelitian ini meliputi tes tertulis berbentuk uraian dan observasi. Teknik analisis data berupa teknik analisis data deskriptif berupa prosentase ketuntasan belajar pada masing-masing siklus. Kriteria ketuntasan belajar jika kelas tersebut telah mencapai 85\% atau minimal $65 \%$ dari KKM. Untuk menghitung persentase di atas menggunakan rumus berikut.

$$
K B=\frac{\sum s \geq 60}{n} \times 100 \%
$$

\section{HASIL \& PEMBAHASAN}

Penelitian ini dilakukan untuk meningkatkan hasil belajar IPA peserta didik melalui model pembelajaran kooperatif tipe PQ4R di kelas V C. Penelitian ini dilakukan sebanyak 2 (dua) siklus dengan 6 (enam) pertemuan. Di dalam masing-masing siklus terdapat 2 (dua) kali pertemuan. Saat penelitian berlangsung selama 6 (enam) kali pertemuan ini, peneliti dibantu oleh kolaborator, yaitu pendidik yang membantu untuk melakukan observasi pada setiap pertemuan dengan mengisi lembar aktivitas pendidik, peserta didik, dan catatan lapangan yang digunakan untuk melihat kelebihan yang akan dipertahankan dalam setiap pertemuan dan kekurangan yang akan diperbaiki pada saat pertemuan berikutnya.

Sebelum dilaksanakan siklus I pembelajaran, dilakukan identifikasi data awal kemampuan analisis siswa mataeri struktur lapisan bumi. Data awal kemampuan analisis siswa sebelum diberi perlakukan strategi PQ4R ditunjukkan pada Tabel 1.

Tabel 1. Data Awal Kemampuan Analisis Siswa Pada Pembelajaran IPA

\begin{tabular}{llccl}
\hline Kriteria & $\begin{array}{l}\text { Rentang } \\
\text { Data }\end{array}$ & Jumlah & Prosentase & $\begin{array}{l}\text { Rata- } \\
\text { rata }\end{array}$ \\
\hline $\begin{array}{l}\text { Belum } \\
\text { mencapai }\end{array}$ & $54-69$ & 17 & $60,71 \%$ & \\
$\begin{array}{l}\text { KKM } \\
\text { Mencapai }\end{array}$ & $70-87$ & 11 & $39,29 \%$ & $68,71 \%$ \\
KKM & & & & \\
\hline
\end{tabular}

Berdasarkan Tabel 1 dapat diperoleh bahwa kemampuan analisis siswa di awal sebelum pelaksanaan PTK masih banyak yang belum mencapi KKM. Rata- rata kemampuan analisis siswa sebesar $68,71 \%$.

\section{Kegiatan Pembelajaran Siklus 1}

Perencanaan Tindakan, rancangan pembelajaran pada siklus 1 yaitu tentang pembelajaran struktur lapisan bumi melalui metode demonstrasi dan diskusi kelompok yang dilaksanakan dua kali pertemuan. Alokasi tiap pertemuan 2 x 35 menit, sistematika kegiatan pembelajaran terdiri dari pendahuluan, inti dan penutup. Adapun skenario pembelajaran siklus 1 adalah sebagai berikut: (1) Proses pembelajaran dilaksanakan dalam bentuk diskusi dan kelompok, (2) Tujuan pembelajaran: Meningkatkan keaktifan siswa dalam mengikuti pelajaran, Meningkatkan kemampuan berpikir kritis dengan merangsang untuk selalu bertanya, Meningkatkan tingkat 
berpikir metakognitif dan berpikir kritis; (3) Media/alat yang digunakan adalah Media Rancangan Lapisan Bumi dan Ringkasan persub bab materi untuk tiap-tiap kelompok. Metode yang digunakan adalah metode ceramah, diskusi dan demonstrasi, Menyiapkan lembar penilaian.

Pelaksanaan Tindakan, proses pembelajaran pertama siklus I dilaksanakan pada 11 Februari 2019. Tujuannya untuk meningkatkan kemampuan analisis dalam memaparkan pendapat mengenai materi struktur lapisan bumi berdasarkan teori dan artikel, serta dapat membuat pertanyaan kritis sehingga permasalahan dalam pembelajaran IPA dapat mengakar ke dalam, dan pengetahuan yang di dapat akan optimal. Adapun alur tindakan kegiatan pembelajaran pada tindakan pertama siklus I adalah sebagai berikut : (1) Siswa diberikan bentuk kontekstual dengan media lapisan bumi (Globe), (2) Siswa diminta untuk memberikan pertanyaan berdasarkan pengamatan globe yang telah dirancang oleh guru, (3) Guru menjelaskan dengan metode ceramah tentang materi struktur lapisan bumi.

Proses pembelajaraan tindakan kedua siklus I dengan melakukan tahapan PQ4R sebagai berikut: (1) Eksplorasi, Siswa dibagi menjadi 4 Kelompok dengan masing-masing anggota 5 orang, Masing-masing kelompok diberikan 1 buah bacaan tentang Lapisan Atmosfer, kemudian siswa diminta untuk: Preview (Meneliti bacaan Lapisan Atmosfer); Question (Memberikan pertanyaan kepada diri sendiri ataupun teman sekelompoknya (bertanya jawab) mengenai materi yang sedang didiskusikan); Read (Membaca secara seksama sub-bab materi yang telah diberikan oleh guru harus secara aktif, tujuannya untuk menjawab pertanyaan-pertanyaan yang sebelumnya telah dibuat); Recite (Menceritakan materi yang telah dibaca dengan seksama, atau dapat menuliskan kembali hal-hal penting yang dianggap penting dalam suatu bacaan tersebut). (2) Elaborasi dimulai dari kegiatan Review (Siswa diminta meninjau kembali materi yang telah dipelajari dan memusatkan diri pada soal-soal dan jawaban serta gagasan-gagasan yang diperoleh pada langkah sebelumnya. Selanjutnya siswa dapat membaca ulang materi itu jika merasa belum yakin dengan jawaban atau gagasangagasannya. (3) Konfirmasi, Reflect (Meninjau kembali, membuat hubungan-hubungan antara pengetahuan yang dimiliki sebelumnya dengan pengetahuan yang baru diperolehnya oleh siswa maupun guru).
Setelah pelaksanaan pembelajaran dilakukan, kemudian dilakukan evaluasi. Hasil evaluasi kemampuan analisis siswa dapat dilihat pada Tabel 2 berikut.

Tabel 2. Kemampuan Analisis Siswa Pada Siklus 1

\begin{tabular}{cc}
\hline Sumber Variasi & Skor \\
\hline Siswa yang tuntas & 19 \\
Siswa yang tidak tuntas & 9 \\
Rata-rata & 75,07 \\
Prosentase Ketuntasan Belajar & $67,80 \%$ \\
\hline
\end{tabular}

Berdasarkan data pada Tabel 2, dapat diperoleh penilaian kemampuan analisis pada siklus I terjadi peningkatan kemampuan analisis pada pembelajaran IPA dengan menggunakan model pembelajaran kooperatif tipe PQ4R di kelas V SDN Cipayung. Data Tabel 2 tampak bahwa terdapat 9 siswa dengan persentase $32,14 \%$ yang belum mencapai KKM, dan sebanyak 19 siswa atau $67,86 \%$ siswa yang sudah tuntas dengan skor rata-rata 75,07. Berdasarkan hasil tersebut, dapat dinyatakan bahwa dibutuhkan perbaikan kemampuan analisis pada siklus II.

Obervasi, selama pelaksanaan kegiatan siklus I juga dilakukan observasi. Hasil selama observasi diperoleh bahwa masih ditemukan aspek-aspek yang mendapatkan kriteria kurang baik meliputi memotivasi siswa, menyampaikan tujuan pembelajaran, pengelolaan waktu, dan siswa antusias. Keempat aspek yang mendapat penilaian kurang baik di atas, merupakan suatu kelemahan yang terjadi pada siklus I. Aktivitas guru yang paling dominan pada siklus I adalah membimbing dan mengamati siswa dalam menemukan konsep yaitu 18,33\%. Aktivitas lain yang persentasenya cukup besar adalah memberi umpan balik/evaluasi/tanya jawab dan menjelaskan materi yang sulit yaitu masingmasing sebesar $15,00 \%$ dan $11,67 \%$. Aktivitas siswa yang paling dominan adalah bekerja dengan sesama anggota kelompok dan mendengarkan / memperhatikan penjelasan guru yaitu $19,92 \%$ dan 18,33\%. Aktivitas lain yang persentasenya cukup besar adalah diskusi antar siswa/antara siswa dengan guru, dan membaca buku yaitu masing-masing 13,95 dan $12,71 \%$. Pada siklus I, secara garis besar kegiatan belajar mengajar pembelajaran dengan Model PQ4R sudah dilaksanakan dengan baik, walaupun peran guru masih cukup dominan untuk memberikan penjelasan dan arahan karena model tersebut masih dirasakan baru oleh siswa. 
Refleksi Siklus I, Refleksi dilaksanakan setelah pembelajaran berlangsung. Berdasarkan hasil refleksi ditemukan beberapa hal yang menjadi kendala pembelajaran dalam tindakan siklus I antara lain sebagai berikut: (1) Guru kurang baik dalam memotivasi siswa dan dalam menyampaikan tujuan pembelajaran; (2) Guru kurang baik dalam pengelolaan waktu, dan (3) Siswa kurang begitu antusias selama pembelajaran berlangsung. Selanjutnya hasil refleksi tersebut diberikan solusi yang menjadi perbaikan pada siklus II meliput: (1) Guru harus lebih terampil dalam memotivasi siswa dan lebih jelas dalam menyampaikan tujuan pembelajaran. Siswa diajak untuk terlibat langsung dalam setiap kegiatan yang dilakukan; (2) Guru harus mendistribusikan waktu secara baik dengan menambahkan informasiinformasi yang dirasa perlu dan memberi catatan; (3) Guru dituntut untuk lebih mengasah keterampilannya dalam memotivasi siswa sehingga siswa bisa lebih antusias.

\section{Kegiatan Pembelajaran siklus II}

Perencanaan Tindakan, rancangan pembelajaran pada siklus II disusun atas dasar refleksi siklus I. Persiapan dimulai dari mempersiapkan perangkat pembelajaran yang terdiri dari perangkat pembelajaran yang berupa rencana pelaksanaan pembelajaran sebanyak 2 pertemuan, lembar kerja peserta didik sebanyak 2 buah, soal tes evaluasi kemampuan analisis, bahan ajar dan media pembelajaran yang digunakan. Selain itu juga dipersiapkan lembar observasi pengelolaan pembelajaran dengan Model PQ4R dan lembar observasi aktivitas guru dan siswa.

Pelaksanaan Tindakan, proses pembelajaran siklus II dilaksanakan pada 18 Februari 2019. Pada dasarnya proses pembelajaran Siklus II bertujuan untuk memperbaiki hasil analisis pada siklus I. Observer kegiatan siklus II ini menggunakan bantuan dua orang guru lain. Pelaksanaan tindakan siklus II dimulai dari guru menyampaikan tujuan pembelajaran, serta menyiapkan literasi berupa video tentang struktur lapisan bumi. Pada tahap eksplorasi, (1) siswa diberikan media konkrit tentang video struktur lapisan bumi, (2) siswa diminta untuk mencari permasalahan dan memberikan pertanyaan berdasarkan pengamatan video yang diberikan oleh guru, (3) siswa dibagi menjadi 4 Kelompok dengan masing-masing anggota 5 orang, (4) masing-masing kelompok diberikan 1 buah bacaan tentang Lapisan Litosfer dan Fungsi-Fungsi Lapisan Litosfer, kemudian siswa diminta untuk: Preview (Meneliti bacaan Lapisan Litosfer dengan penayangan video), Question (Memberikan pertanyaan kepada diri sendiri ataupun teman sekelompoknya (bertanya jawab) mengenai materi yang sedang didiskusikan), Read (Membaca secara seksama sub-bab materi yang telah diberikan oleh guru harus secara aktif, tujuannya untuk menjawab pertanyaan-pertanyaan yang sebelumnya telah dibuat, Recite (Menceritakan materi yang telah dibaca dengan seksama, atau dapat menuliskan kembali hal-hal penting yang dianggap penting dalam suatu bacaan tersebut).

\section{Selanjutnya dilakukan kegiatan} elaborasi meliputi Review dimana siswa diminta meninjau kembali materi yang telah dipelajari dan memusatkan diri pada soal-soal dan jawaban serta gagasan-gagasan yang diperoleh pada langkah sebelumnya. Selanjutnya siswa dapat membaca ulang materi itu jika merasa belum yakin dengan jawaban atau gagasan-gagasannya.

Pada tahap konfirmasi, kegiatan yang dilakukan berupa Reflect yaitu siswa meninjau kembali, membuat hubungan-hubungan antara pengetahuan yang dimiliki sebelumnya dengan pengetahuan yang baru diperolehnya. Pada tahap ini, siswa diharapkan untuk berpikir kritis tentang kesimpulan yang diperoleh pada tahap review, caranya dengan menyelesaikan permasalahan yang berupa soa-soal dengan menggunakan konsep yang telah dipelajarinya. Guru berperan untuk pembenaran konsep, Dengan refleksi ini, siswa dapat memperoleh sesuatu yang berguna bagi dirinya tentang apa yang baru dipelajarinya.

Observasi Pelaksanaan, Berdasarkan hasil observasi selama proses pembelajaran pada siklus II, tampak aspek-aspek yang diamati pada kegiatan belajar mengajar (siklus II) yang dilaksanakan oleh guru dengan menerapkan pembelajaran dengan Model PQ4R mendapatkan penilaian yang cukup baik dari pengamat. Secara umum tidak ada penilaian yang kurang. Meskipun begitu, ada beberapa aspek yang perlu mendapatkan perhatian untuk penyempurnaan penerapan pembelajaran selanjutnya. Aspek - aspek tersebut diantaranya aspek memotivasi siswa, aspek dalam membimbing siswa untuk merumuskan / menyimpulkan suatu konsep, dan aspek dalam mengelola waktu.

Aktivitas guru yang paling dominan pada siklus II adalah membimbing dan mengamati siswa dalam menemukan konsep yaitu $21,67 \%$. Aktivitas siswa yang paling dominan pada siklus II adalah bekerja dengan 
sesama anggota kelompok yaitu $21,04 \%$ dan meningkat jika dibandingkan pada siklus I. Selain itu, aktivitas siswa yang mengalami peningkatan lainnya adalah membaca buku $(12,08 \%)$, menyajikan hasil pembelajaran $(4,58 \%)$, menanggapi/mengajukan pertanyaan/ide $(5,42 \%)$, dan mengerjakan tes evaluasi $(10,83 \%)$. Setelah pelaksanaan siklus II selesai, siswa diberikan evaluasi untuk mengukur kemampuan analisis. Data kemampuan analisis siswa pada siklus II dapat dilihat pada Tabel 3.

Tabel 3. Kemampuan Analisis Siswa Pada Siklus II

\begin{tabular}{cc}
\hline Sumber Variasi & Skor \\
\hline Siswa yang tuntas & 24 \\
Siswa yang tidak tuntas & 4 \\
Rata-rata & 85,86 \\
Prosentase Ketuntasan Belajar & $85,71 \%$ \\
\hline
\end{tabular}

Berdasarkan Tabel 3 siklus II, terjadi peningkatan kemampuan analisis pada pembelajaran IPA dengan menggunakan strategi PQ4R di kelas V SDN Cipayung. Tampak bahwa siswa yang mendapatkan nilai belum mencapai KKM hanya 4 siswa dengan persentase $14,29 \%$, dan untuk siswa lainnya yaitu 24 siswa telah tuntas dan mencapai KKM atau setara dengan persentase $85,71 \%$. Rata rata kemampuan analisis siswa sebesar 85,86 meningkat dibandingkan pada siklus I.

Refleksi Siklus II, dilakukan setelah selesai pembelajaran. Hasil refleksi diperoleh informasi bahwa selama proses belajar mengajar guru telah melaksanakan semua pembelajaran dengan baik. Meskipun ada beberapa aspek yang belum sempurna, tetapi persentase pelaksanaannya untuk masingmasing aspek cukup besar. Data hasil pengamatan juga diketahui bahwa siswa aktif selama proses belajar berlangsung. Perbaikan tampak dilakukan selama siklus II berlangsung. Kemampuan analisis siswa pada siklus II mencapai ketuntasan. Pada siklus II pelaksanaan strategi PQ4R berjalan dengan baik dan dilihat dari aktivitas siswa serta hasil belajar siswa pelaksanaan proses belajar mengajar sudah berjalan dengan baik pula. Hasil tersebut disimpulkan bahwa tidak diperlukan revisi terlalu banyak, tetapi yang perlu diperhatikan untuk tindakan selanjutnya adalah memaksimalkan dan mempertahankan apa yang telah ada dengan tujuan agar pada pelaksanaan proses belajar mengajar selanjutnya penerapan pembelajaran dengan strategi PQ4R dapat meningkatkan proses belajar mengajar sehingga tujuan pembelajaran dapat tercapai. Perbandingan kemampuan analisis siswa dari sebelum hingga dilakukan siklus I dan siklus II dapat dilihat pada Gambar 2.

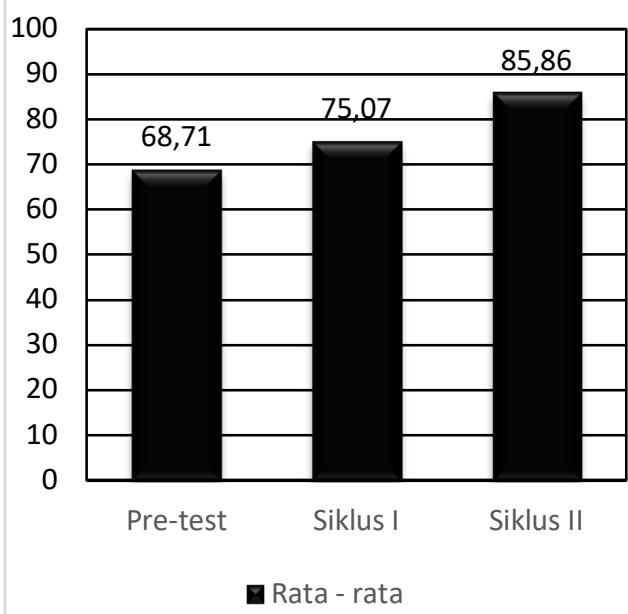

Gambar 2. Perbandingan Rata-rata Kemampuan Analisis Siswa

Berdasarkan Gambar 2, bahwa rata-rata kemampuan analisis siwa meningkat dari sebelum diterapkan strategi PQ4R sebesar 68,71 meningkat menjadi 75,07 pada siklus I. Rata - rata kemampuan analisis siswa setelah siklus II juga meningkat menjadi 85,86. Melalui hasil penelitian ini dapat dilihat bahwa pembelajaran dengan menggunakan strategi PQ4R memiliki dampak positif dalam meningkatkan kemampuan analisis siswa. Hal ini dapat dilihat dari semakin meningkatnya pemahaman serta kemampuan analisis yang seimbang dengan pemikiran kritis siswa dalam materi Struktur Lapisan Bumi. Pada siklus II dapat dinyatakan bahwa secara klasikal, ketuntasan belajar siswa tercapai dengan baik. Berdasarkan hasil observasi, aktivitas siswa dalam proses pembelajaran dengan strategi PQ4R dalam setiap siklus mengalami peningkatan. Hal ini berdampak positif terhadap kemampuan analisis siswa yaitu dapat ditunjukkan dengan meningkatnya nilai ratarata siswa pada setiap siklus yang terus mengalami peningkatan. Aktivitas siswa dalam proses pembelajaran IPA di kelas 5 dengan materi Struktur Lapisan Bumi yang menggunakan model pembelajaran kooperatif dengan jenis PQ4R yang paling dominan adalah bekerja dengan menggunakan alat/media, mendengarkan/ memperhatikan penjelasan guru, dan diskusi antar siswa/antara siswa dengan guru. Jadi dapat dikatakan bahwa aktivitas siswa dapat dikategorikan aktif. Aktivitas guru selama pembelajaran telah 
melaksanakan langkah - langkah pembelajaran dengan strategi PQ4R dengan baik. Hal ini terlihat dari aktivitas membimbing dan mengamati siswa dalam mengerjakan kegiatan LKPS/menemukan konsep, menjelaskan materi yang sulit, memberi umpan balik / evaluasi / Tanya jawab dimana prosentase untuk aktivitas tersebut cukup besar.

Strategi pembelajaran PQ4R yang digunakan dapat berpengaruh terhadap kemampuan analisis pada pembelajaran IPA siswa kelas 5, karena strategi PQ4R membuat siswa dapat mengembangkan pengetahuan dan pemahaman yang telah diberikan oleh guru dalam bentuk narasi atau teks bacaan (Adlina et al., 2018; Ahmad \& Damayanti, 2013). Siswa dituntut untuk menjadi lebih aktif dalam mencari suatu intisari bacaaan dan pengembangan pengetahuan dari teks bacaan (Ulfa, 2019). Terjadi interaksi antara siswa dan guru dalam proses pembelajaran dan tidak bersifat monoton. Hal ini yang membuat kemampuan analisis siswa pada pembelajaran IPA menjadi meningkat.

\section{KESIMPULAN \& SARAN}

Berdasarkan analisis data, dapat disimpulkan bahwa rata-rata kemampuan analisis siwa meningkat dari sebelum diterapkan strategi PQ4R sebesar 68,71 meningkat menjadi 75,07 pada siklus I. Rata rata kemampuan analisis siswa setelah siklus II juga meningkat menjadi 85,86 . Melalui hasil penelitian ini dapat dilihat bahwa pembelajaran dengan menggunakan strategi PQ4R memiliki dampak positif dalam meningkatkan kemampuan analisis siswa. Hal ini dapat dilihat dari semakin meningkatnya pemahaman serta kemampuan analisis yang seimbang dengan pemikiran kritis siswa dalam materi Struktur Lapisan Bumi. Pada siklus II dapat dinyatakan bahwa secara klasikal, ketuntasan belajar siswa tercapai dengan baik. Berdasarkan hasil observasi, aktivitas siswa dalam proses pembelajaran dengan Model PQ4R dalam setiap siklus mengalami peningkatan. Untuk penelitian selanjutnya, dapat menggali lebih dalam terkait masing-masing komponen kemampuan analisis siswa yang diberikan perlakuan strategi PQ4R sehingga dapat tergambar lebih detail.

\section{DAFTAR PUSTAKA}

Achmad, P. I. (2016). Pengaruh Inkuiri Terbimbing Terhadap Kemampuan
Analisis Siswa Kelas IV SD Se-Gugus Boden Powell Gebang. Jurnal Pendidikan Guru Sekolah Dasar, 5(19), 1861-1869. http://journal.student.uny.ac.id/ojs/index. php/pgsd/article/view/2548/2183

Adlina, N., Helmi, \& Rusli, M. A. (2018). Penerapan Strategi Pembelajaran Preview, Question, Read, Reflect, Recite, Review Terhadap Kemampuan Berpikir Kreatif Dan Hasil Belajar Fisika Peserta Didik SMAN 1 Tinambung. Jurnal Sains Dan Pendidikan Fisika, 14(1), 40-45.

Ahmad, F. Z., \& Damayanti, M. I. (2013). Penerapan Strategi PQ4R untuk Meningkatkan Keterampilan Membaca Pemahaman Pada Siswa Sekolah Dasar. JPGSD, 1(2), 1-8.

Al-Tabany, T. I. B. (2014). Mendesain Model Pembelajaran Inovatif, Progresif, dan Kontekstual. Konsep, Landasan, dan Ilmplementasinya pada Kurikulum 2013 (Kurikulum Tematik Integratif/KTI). Kencana.

Astriani, D., Susilo, H., Suwono, H., \& Lukiati, B. (2017). Profil Keterampilan Berpikir Analitis Mahasiswa Calon Guru IPA Dalam Perkuliahan Biologi Umum. Jurnal Penelitian Pendidikan IPA, 2(1), 66-70.

https://doi.org/10.26740/jppipa.v2n2.p6670

Dewi, E. M., Annisa, M., \& Kunadi, D. (2018). Pengembangan Modul IPA Berbasis Keterampilan Proses Sains Untuk Mengembangkan Karakter Pada Siswa Kelas V A SDN 007 Tarakan. LENSA (Lentera Sains): Jurnal Pendidikan IPA, $8(2)$, 54-66.

https://doi.org/10.24929/lensa.v8i2.36

Irianto, D. M., Nadiroh, \& Nuryadin, S. (2015). Pengaruh Model Pembelajaran dan Hasil Belajar IPA Terhadap Kemampuan Memcahkan Masalah Lingkungan Hidup. PLPB: Pendidikan Lingkungan Dan Pembangunan Berkelanjutan, 16(2), 122144. https://doi.org/10.21009/PLPB

Mukhbitah, I., Mulyasari, E., \& Robandi, B. (2019). Penerapan Metode Eksperimen Untuk Meningkatkan Pemahaman Konsep IPA di Kelas V Sekolah Dasar. Jurnal Pendidikan Guru Sekolah Dasar, 4(2), 312-321. https://doi.org/10.17509/jpgsd.v4i2.2056 1

Nawawi, S., Oviyanti, F., \& Faizah, U. (2017). Pengaruh Model Generative Learning terhadap Kemampuan Analisis Siswa 
pada Materi Sistem Saraf Manusia. Edubiotik, 2(2), 30-39. https://doi.org/10.15797/concom.2019..2 3.009

Novita, S., Santosa, S., \& Rinanto, Y. (2016). Perbandingan Kemampuan Analisis Siswa melalui Penerapan Model Cooperative Learning dengan Guided Discovery Learning. Proceeding Biology Education Conference, 13(1), 359-367.

Pasinggi, Y. S. (2016). Peningkatan Hasil Belajar Siswa tentang Pembelajaran Soal Cerita Operasi Hitung Campuran Melalui Model Kooperatif Tipe STAD di Kelas III SDN 44 Parepare. Jurnal Publikasi Pendidikan, 6(2), 111-118.

Pramana, K. A. B., Lasmawan, I. W., \& Marhaeni, A. A. I. N. (2014). Pengaruh Penerapan Pembelajaran PQ4R Kontekstual Terhadap Hasil Belajar IPS Dan Sikap Peduli Lingkungan Siswa Kelas V SD Gugus I Gianyar. Jurnal Pendidikan Dasar Ganesha, 4(1), 111.

Qomariya, Y., Muharrami, L. K., Hadi, W. P., \& Rosidi, I. (2018). Profil Kemampuan Berpikir Analisis Siswa SMP Negeri 3 Bangkalan dengan Menggunakan Metode Pictorial Riddle Dalam Pembelajaran Inkuiri Terbimbing. Journal of Natural Science Education Research, 1(1), 9-18. https://journal.trunojoyo.ac.id/nser/article /view/4172

Rosadi, I., \& Sunarno, W. (2018). Profil Keterampilan Berpikir Analitis Siswa Kelas XI MIA Madrasah Aliyah Negeri 2 Ngawi. Seminar Nasional Biologi Pendidikan Biologi UKSW, 250-256.

Sayekti, I. C. (2016). Pembelajaran IPA Menggunakan Inkuiri Terbimbing Melalui Eksperimen dan Demonstrasi Ditinjau Dari Kemampuan Analisis Siswa. Jurnal Pendidikan Sains, 4(1), 616.https://doi.org/10.26714/jps.4.1.2016. 6-16

Ulfa, M. (2019). Strategi Preview, Question, Read, Reflect, Recite, Review (PQ4R) Pada Pemahaman Konsep Matematika. Mathema Journal, 1(1), 48-55. 